\title{
A Note about the Book Reviews in This Issue of Technical Services Quarterly
}

Glenda A. Thornton

Cleveland State University, g.thornton@csuohio.edu

Follow this and additional works at: https://engagedscholarship.csuohio.edu/msl_facpub

Part of the Library and Information Science Commons

How does access to this work benefit you? Let us know!

\section{Original Citation}

Thornton, G. A., (2011). A note about the book reviews in this issue of Technical Services Quarterly, Technical Services Quarterly, 28, 1, 109-110.

\section{Repository Citation}

Thornton, Glenda A., "A Note about the Book Reviews in This Issue of Technical Services Quarterly" (2010). Michael Schwartz Library Publications. 81.

https://engagedscholarship.csuohio.edu/msl_facpub/81

This Editorial is brought to you for free and open access by the Michael Schwartz Library at EngagedScholarship@CSU. It has been accepted for inclusion in Michael Schwartz Library Publications by an authorized administrator of EngagedScholarship@CSU. For more information, please contact library.es@csuohio.edu. 


\section{A note about the book reviews in this issue of Technical Services Quarterly}

As readers of review columns might speculate, column editors are constantly on the lookout for new books that will interest their readership. And, of course, a significant function of any book review column is to help the readership keep abreast of new ideas. To accomplish this, I am constantly scanning publishers' catalogs looking for titles marked "forthcoming" or "new." Last fall, in perusing the latest ALA catalog, my eye was immediately drawn to a number of books marked "new" on the general topic of archival issues. Aha, I thought, what a wonderful selection of titles on a thematic topic that is seemingly becoming ever more important to greater numbers of libraries! However, upon closer inspection, I came to the conclusion that these books were not newly published, but just new to the ALA catalog. Upon discussing this with a representative of the publishing branch of ALA, I ascertained that this was indeed the case. The American Library Association has embarked on a new venture, that of marketing titles for societies and associations that have a close relationship to librarianship. Thus, a number of fairly recently published titles from the Society of American Archivists were advertised in the Fall/Winter 2010 ALA Editions catalog. As I read about these titles, I found myself ordering all of them for my library as they cover topics that are of increasing interest to us. So, I decided to break from tradition, and publish new reviews of these slightly older titles, thus introducing them to the readership of Technical Services Quarterly — or at least to those of you who may not have already discovered them. I read most of these titles myself (have reviewed one of them) and found them particularly helpful with some grants that we are pursuing. Interestingly enough, as I worked with these titles, they lead me to an important new book (different publisher) that also relates to the topic of this column, and I have included it as well.

Below you will find my review of the title, Planning New and Remodeled Archival Facilities by Thomas P. Wilsted, which also includes a great deal of information on the preservation of different formats of materials; a title specifically on the challenges of film preservation written by Kent State library science professor Karen Gracy and reviewed by a film producer; and an outstanding title on the archival care and management of photographs written by staff from the Library of Congress. These three titles are followed by Navigating Legal Issues in Archives by Menzi L. Behrnd-Klodt and a recently published book, Copyright and Cultural Institutions: Guidelines for Digitization for U.S. Libraries, Archives, and Museums by Peter B. Hirtle, Emily Hudson, and Andrew T. Kenyon.

For anyone supporting or working in the special collections department of a library, an archive (either a stand-alone facility or one associated with a cultural institution) or museum, the content of these five books provide information that is essential to a successful operation. I found all of them very informative and have added personal copies to my own bookshelf. I hope that some of you will also find the following reviews informative and that these titles will help you with your own work.

Glenda Thornton 
Reviews Editor 